\title{
Typification of two natural hybrids in Rumex (Polygonaceae)
}

\section{Artur Pliszko $^{1}$}

Summary. Rumex $\times$ borbasii Błocki, a natural hybrid between $R$. confertus Willd. and $R$. obtusifolius L., and $R$. $\times$ skofitzii Błocki, a natural hybrid between $R$. confertus and R. crispus L., are lectotypified based on critical revision of herbarium material deposited in KRA, KRAM, LW and WA, forming part of the collections of Bronisław Błocki.

Key Words. herbarium, isolectotype, lectotype, protologue, taxonomy.

\section{Introduction}

The genus Rumex L. (Polygonaceae) comprises about 200 species distributed worldwide (Mosyakin 2005) and is known as one of the richest genera in natural hybrids, especially within the subgenus Rumex (Rechinger 1984; Daehler \& Carino 2001). Moreover, there are also artificial hybrids of economic importance (Hujerová et al. 2013).

Rumex $\times$ borbasii Błocki, a natural hybrid between $R$. confertus Willd. and R. obtusifolius L., and R. ×skofitzii Błocki, a natural hybrid between $R$. confertus and $R$. crispus L., were described from western Ukraine by Bronisław Błocki, a Polish botanist, and validly published in the late 19th century (Błocki 1888b, 1889). Both hybrids have been reported from several countries in northern, central and eastern Europe (Stace et al. 2015) and they occur usually with their parent species in anthropogenic habitats (Błocki 1888a, 1888b, 1892; Snogerup 2000; Stace et al. 2015).

Rumex $\times$ skofitzii resembles $R$. confertus in size but has narrower stem leaves with crisped margins and lax panicles with lanceolate crisped bracts. Moreover, the mature tepals possess largely rounded tubercles similar to those of $R$. crispus and the tepal apex is less rounded than in $R$. confertus (Stace et al. 2015). Rumex $\times$ borbasii has the wide basal and lower stem leaves similar to those of $R$. confertus, but they are thinner in texture and the midrib bears some indumentum abaxially resembling $R$. obtusifolius. The panicle of $R$. $\times$ borbasii is lax with irregularly maturing tepals, however, the well-developed tepals are tubercled, broad with a subacute apex, and bear shortly toothed margins (Stace et al. 2015). The flowers of $R$. ×skofitzii and $R$. $\times$ borbasii are irregular in maturing and appear sterile, however, some individuals of both hybrids produce a low number of seeds (Snogerup 2000; Stace et al. 2015). Interestingly, in countries where $R$. confertus is considered alien (e.g. Lithuania, Poland, Sweden, UK) its hybrids also should be treated as alien taxa, following the concept proposed by Pyšek et al. (2004), and a proper recognition of spontaneous hybrids between alien $R$. confertus and its native congeners is important to control their negative impacts.

Although the names of Rumex $\times$ skofitzii and $R$. $\times$ borbasii are adopted by other authors (Snogerup 2000; Stace et al. 2015), they have never been typified. Therefore, after critical revision of the original material, $R$. $\times$ skofitzii and $R \times$ ×borbasii are lectotypified here.

\section{Materials and Methods}

Selection and designation of type specimens followed the rules set out in the International Code of Nomenclature for Algae, Fungi, and Plants (Turland et al. 2018). Original herbarium material of Rumex $\times$ skofitzii and $R$. $\times$ borbasii was critically revised in 2016 based on collections deposited in KRA, KRAM, LW and WA, and compared to data included in the protologues (Błocki 1888b, 1889). In addition, the resources on JSTOR Global Plants (https://plants.jstor.org) and Virtual Herbaria (http:// www.herbarium.univie.ac.at) were also checked.

\section{Typification}

Rumex xborbasii Btocki (1889: 155). Type: Ukraine, Holosko (Lviv), unknown date, B. Btocki s.n. (lectotype LW [LW00058082]!, selected here; isolectotype LW [LW00058081]!). Fig. 1.

NOTES. Originally, the hybrid involving Rumex confertus and $R$. obtusifolius was described under the name $R$. $\times$ kerneri Błocki (Błocki 1888a). However, its name was changed when Błocki (1889) found out that the epithet had already been applied to another Rumex species by Borbás (1884), namely R. kerneri Borbás.

\footnotetext{
Accepted for publication 1 March 2019. Published online 10 April 2019

1 Department of Taxonomy, Phytogeography and Paleobotany, Institute of Botany, Jagiellonian University, Gronostajowa 3, 30-387 Kraków, Poland. e-mail: artur.pliszko@uj.edu.pl
} 


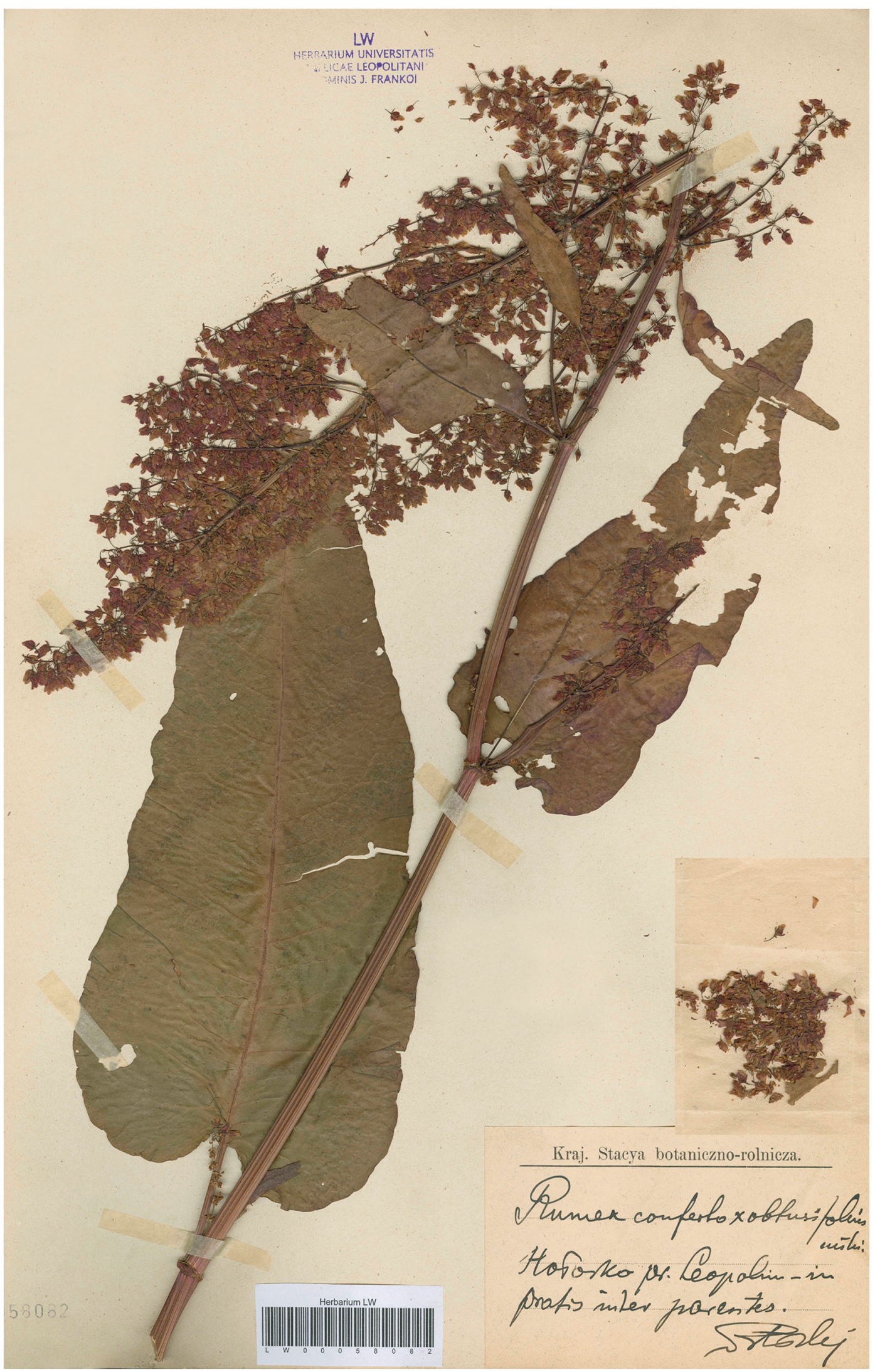

Fig. 1. Lectotype of Rumex xborbasii (B. Błocki s.n. LW [LW00058082]). 


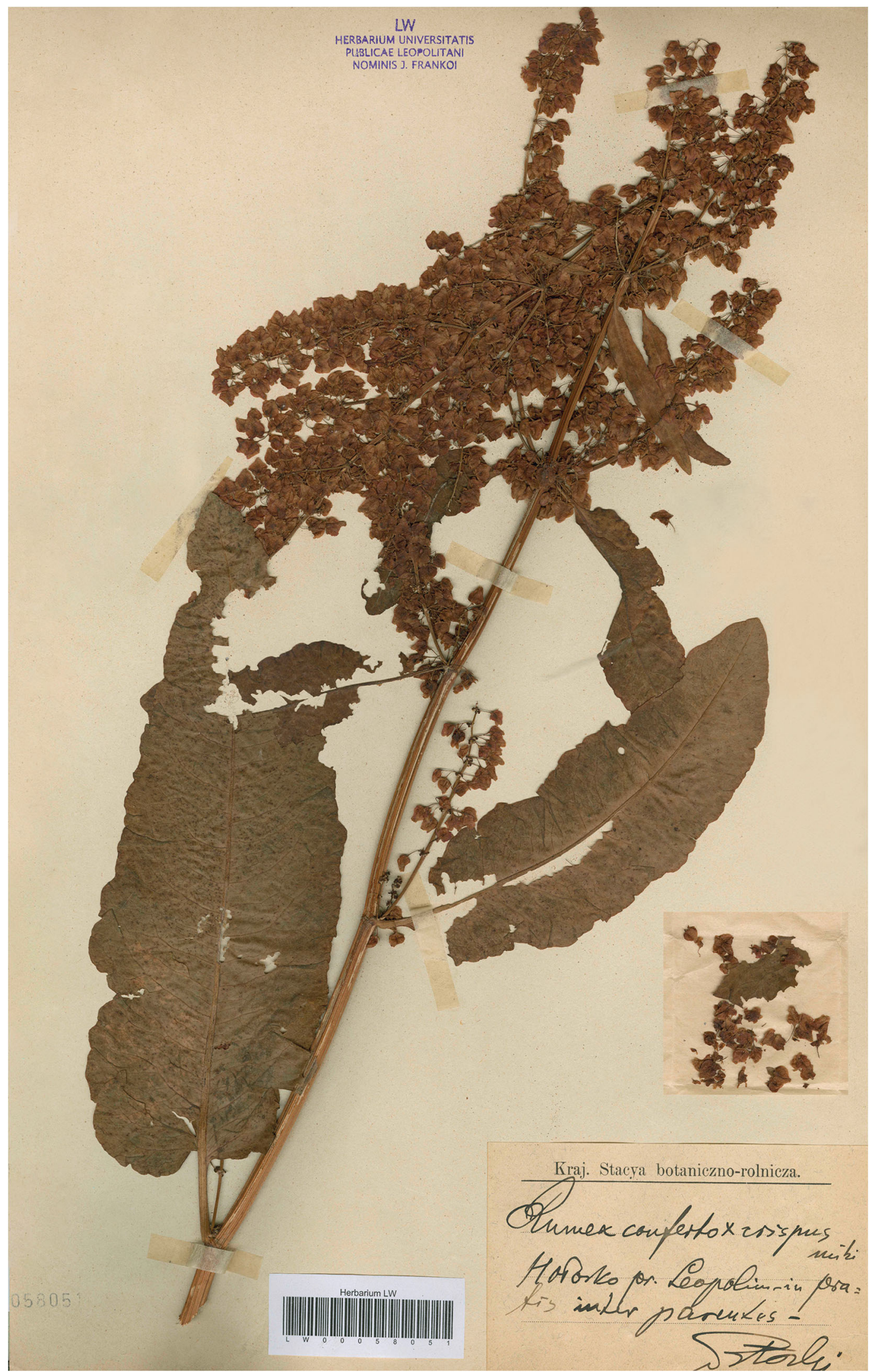

Fig. 2. Lectotype of Rumex xskofitzii (B. Błocki s.n. LW [LW00058051]). 
The name of $R . \times$ borbasii was given by Błocki in honour of Vincze von Borbás, a Hungarian botanist. In the protologue of $R . \times$ borbasii (Błocki 1888a, 1889), two localities near Lviv (i.e., Zamarstyniv and Holosko Velyke) were mentioned as loci classici. Nowadays, Zamarstyniv is one of the boroughs of the city of Lviv and Holosko Velyke is a suburb of Lviv (western Ukraine). The specimens proposed herein as lectotype and isolectotype were collected in Holosko (short version of the name of Holosko Velyke) and are the most informative original material available and they match Błocki’s protologue.

Rumex ×skofitzii Błocki (1888b: 340). Type: Ukraine, Holosko (Lviv), unknown date, B. Btocki s.n. (lectotype LW [LW00058051]!, selected here; isolectotypes LW [LW00058050]!, KRAM [KRAM129323]!). Fig. 2.

NOTES. The name of Rumex $\times$ skofitzii was given by Błocki to honour Alexander Skofitz, an Austrian botanist and pharmacist. In the protologue of $R$. ×skofitzii, Błocki (1888b) did not provide a detailed description of the locus classicus, indicating only that the hybrid was found near Lviv. In the present work, I decided to choose the type specimens collected by Błocki in Holosko, formerly a village situated near Lviv. Morphological characters of specimens selected here as lectotype and isolectotype of $R$. $\times$ skofitzii are as described in the protologue.

\section{Acknowledgements}

I would like to thank the curators of KRA and KRAM for providing access to Bronisław Błocki's collections and the curators of LW and WA for sending me digitised images of herbarium sheets.

Open Access This article is distributed under the terms of the Creative Commons Attribution 4.0 International License (http://creativecommons.org/ licenses/by/4.0/), which permits unrestricted use, distribution, and reproduction in any medium, provided you give appropriate credit to the original author(s) and the source, provide a link to the Creative Commons license, and indicate if changes were made.

\section{References}

Błocki, B. (1888a). Rumex Kerneri n. hybr. (R. conferto $\times$ obtusifolius). Oesterr. Bot. Z. 38: 365 - 366. (1888b). Rumex Skofitzii n. hybr. (R. conferto $\times$ crispus). Oesterr. Bot. Z. 38: 340 - 341.

(1889). Flora von Oesterreich-Ungarn.

B. Galizien. Oesterr. Bot. Z. 39: $154-155$.

(1892). Ein kleiner Beitrag zur Flora von Galizien. Oesterr. Bot. Z. 42: 349 - 352.

Borbás, V. (1884). Temes megye vegetatiója (Flora Comitatus Temesiensis). Emlékmüböl, Nyomatott Magyar Testvéreknél, Temesvárot.

Daehler, C. C. \& Carino, D. A. (2001). Hybridization between native and alien plants and its consequences. In: J. L. Lockwood \& M. L. McKinney (eds), Biotic Homogenization, pp. 81 102. Kluwer Academic/Plenum Publishers, New York.

Hujerová, R., Gaisler, J., Pavlů, L., Pavlů, V. \& Mandák, B. (2013). Hybrid of Rumex patientia $\times$ Rumex tianschanicus (Rumex OK-2) as a potentially new invasive weed in Central Europe. Grassland Science in Europe 18: 466 - 468.

Mosyakin, S. L. (2005). Rumex Linnaeus. In: Flora of North America Editorial Committee, Flora of North America North of Mexico, Vol. 5, Magnoliophyta: Caryophyllidae, part 2: 489 - 533. Oxford University Press, New York, Oxford.

Pyšek, P., Richardson, D. M., Rejmánek, M., Webster, G. L., Williamson, M. \& Kirschner, J. (2004). Alien plants in checklists and floras: towards better communication between taxonomists and ecologists. Taxon 53: $131-143$.

Rechinger, K. H. (1984). Rumex (Polygonaceae) in Australia: a reconsideration. Nuytsia 5: 75 - 122.

Snogerup, S. (2000). Rumex L. subgenus Rumex. In: B. Jonsell (ed.), Flora Nordica, Vol. 1: 281 - 318. Bergius Foundation, Stockholm.

Stace, C. A., Preston, C. D. \& Pearman, D. A. (2015). Hybrid flora of the British Isles. Botanical Society of Britain and Ireland, Bristol.

Turland, N. J., Wiersema, J. H., Barrie, F. R., Greuter, W., Hawksworth, D. L., Herendeen, P. S., Knapp, S., Kusber, W.-H., Li, D.-Z., Marhold, K., May, T. W., McNeill, J., Monro, A. M., Prado, J., Price, M. J. \& Smith, G. F. (eds) (2018). International Code of Nomenclature for algae, fungi, and plants (Shenzhen Code) adopted by the Nineteenth International Botanical Congress Shenzhen, China, July 2017. Regnum Veg. 159, Koeltz Botanical Books, Glashütten.

\section{Publisher's Note}

Springer Nature remains neutral with regard to jurisdictional claims in published maps and institutional affiliations. 